\title{
Teacher education courses: Are they germane to classroom practice for novice teachers?
}

\author{
Nani Babu Ghimire \\ Tribhuvan University, Nepal
}

\begin{abstract}
The article analyses novice teachers' perception on the pre-service teacher education courses of English at Tribhuvan University (TU) and to describe their beliefs and satisfaction on teaching profession. It also aims to describe novice teachers' practice to implement the acquired knowledge and skills of these courses in their teaching field. Narrative inquiry was adopted as a research method and three novice teachers of community school of Sindhuli were selected as informants following purposive sampling technique. The semi-structured interview was used in order to elicit in depth data from the participants. Content analysis framework was used to analyse data by developing main themes into codes and using them to look for relevant features in the text. The findings divulge that pre-service teacher education courses are supportive and satisfactory for novice teachers as it provides methodological skill and theoretical knowledge to them to teach in the classroom. The novice teachers, who strongly believe in the teaching profession, also think that the contents are theoretically appropriate but they lack some practical applications.
\end{abstract}

Keywords:Teacher Professional Development, Pre-service Teacher Education Courses, Novice Teachers,

\section{Introduction}

As a school student some 25 years ago, I felt that we were weak in English. I thought that teacher were not qualified, they did not have minimum qualification to teach, they were inexperienced, and that they did not have any ideas of teaching approaches, methods and techniques. In 2003, I started to teach in a secondary school myself and I found that the situation is the same like it was when I was a student. When I became an English teacher, many of my colleagues had a teaching degree, and they knew about teaching methodology. Despite that students failed in English in large numbers. Now, as a teacher-educator, when I visit schools to supervise practicing teachers (undergraduate and/or postgraduate trainee teachers), I find that the situation has not changed much. There is little progress in teaching English. The result in English is very dismal even if we have trained and experienced teachers with required qualification and knowledge of teaching learning methodologies. This situation inspired me to carry out a smallscale research. I chose the area of teacher education involving novice teachers. I studied their perceptions and practices on 
the pre-service teacher education courses of English in TU.

Novice teachers are new teachers who have completed pre-service teacher education courses, and have passed the Teacher Service Commission examination but have little or no teaching experience. Novice teachers, according to Farrell (2012, as cited in Akcan, 2015, p.1), are those who have started to teach English within three years of completing their language teacher education program. They are fresh out of teacher-training college, and are usually anxious to get better at their practice. However, they often get lost in the routine of planning, teaching and marking. Similarly, Kim and Roth (2011, p.4) define a novice teacher as "any teacher with five years or less experience". In other words, novice teachers are those who have less than five years of teaching experience and need supportive environments that foster continuous learning, collaboration, and professional growth. Additionally, GoffKfouri (2013, p.1) states," pre-service teachers face several challenges as they strive to achieve excellence. Not only must they prove they master their subject matter, but they must also show competence in classroom management, methodology, and assessment". Depending on the area, development from novice teachers to professional teachers may take a shorter or longer period of time.

Teacher education program is one of the most important components of teacher professional development (TPD). Through it, school teachers, who are considered mentors of society, are prepared and produced (Melita \& Katitia, 2015). Teacher education refers to the policies, procedures, and provision designed to equip teachers with the knowledge, attitude, behavior and skills they require to perform their tasks effectively in the classroom, school and wider community. In this regard, Kafu (2003) said that teacher education is ostensibly designed, developed and administered to produce school teachers for the established system of education. Likewise, Teacher Student Union of Finland has justified teacher education in Goals for Teacher Education (2016-2019, pp. 1-2) as:

Teacher education provides students with a range of skills that are needed in order to work and improve in global and multinational information society [...] Teacher education is built on research and it builds a base for research-based teaching and encourages students to update their own skills.

Some of the TPD schemes include teacher education programs, training programs, workshop, seminar, symposium, conference organized and conducted by higher education institutions, organisations and agencies involved in teacher development. Loughran (2006) contend that teacher education is the pre-service and in-service teacher preparation where students of teaching seek to develop knowledge and skills of teaching and to learn how to competently apply these in practice. These views summarize the importance and the role of teacher education in the preparation of quality teachers.

My own experience of working as a teacher as well as a teacher educator prompted me to study the impact these pre-service teacher education programs have on the achievement of the students in learning English. The present study, therefore, looks into a possible link between teachers' expertise and students' achievement. It also explores the effectiveness of pre-service teacher education courses of English in TU. In particular, it addresses questions like 'what the practice and perception of teaching English the young graduates have'. 


\section{Literature review}

Pre-service teacher education course is typically designed to teach the students who want to engage in teaching learning process after completing the course. Discussing pre-service teacher education, Freeman (2001, p. 72) has written:

Teacher education is the sum of experiences and activities through which individuals learn to be language teachers. This learning can be taught, as in courses, or acquired by means of experience, which must guarantee that the pre-service teachers can develop all the skills required to become professional teachers.

Pre-service teacher education courses make the teachers able to master their subject matter and to show competence in classroom management, methodology, and assessment. In this respect, Mergler\& Spooner-Lane (2012, p.66) asserted that pre-service teacher education programs aim to prepare graduates to become quality teachers equipped with pedagogical practices that will serve to meet the increasing demands associated with the teaching profession. One way to improve the quality of the teaching profession is to introduce certification of teachers based on national professional teaching standards. Similarly, in Akcan (2016) study the participating novice teachers agreed that their teacher education program provided them with a good foundation in English language teaching. However, they thought that there was more emphasis on theory rather than practice and that theory and practice were not integrated in the program. Similarly, Tarone and Allwright (2005, p.12) suggests that the "differences between the academic course content in language teacher preparation program and the real conditions that novice language teachers are faced with in the language classroom appear to set up a gap that cannot be bridged by beginning teacher learners". Additionally, Beltman, Glass, Dinham, Chalk and Nguyen, (2015, p.241) concluded that newly graduated preservice teachers had optimism about their profession and attitudes that were positive, confident, capable and happy. In Okas, Schaaf, and Krull, (2014, p.340) study, novice teachers saw the teacher's role as making students work independently[...] the younger teachers had greater hopes and expectations.

Conforming with studies above, Faez and Valeo (2012) found that novice teachers enhanced their efficiency through classroom experiences, and they condemned teacher education programs because they did not deliver the sort of knowledge that teachers needed most (Johnson 1996). Similarly, novice teachers, complained that they learnt too much theory and too little practical knowledge from such a program. Discussing the problems of novice teachers Cakmak (2013, p. 59) concludes that:

Major challenges that novice teachers face with time management; student assessment; negative relationships with teachers, principals, lack of time (to plan, prepare, carry out administrative duties); establishing positive relationships with students; the need to establish authority; difficulties in aligning instructional techniques to the subject content and evaluation.

Satisfaction and beliefs on teaching help teachers adopt their teaching strategies for coping with their daily language teaching challenges, influence their general wellbeing, and in turn, shape learning environment and student learning.

A number of points emerge from a survey of the related literature on teacher education (TE) programs and practices: First TE has to be grounded in the reality of the practice of English language teaching. 
Second, TE programs and practices should be made functionally accountable in terms of the quality of graduates they produce . Third, a standard for the selection of teachers have to be maintained in issuing teaching license and in employment processes. Fourth, preservice programs of preparation teachers practice oriented, rather than theory oriented. For this reason, the concerned government departments and TE agencies should be active and responsible partners in TE programs and practices. And finally, teacher educators and supervising teachers should be accomplished professional practitioners with extensive expertise of the field who could inculcate not only positive attitude towards the profession.

The challenge for developing quality teachers of English who are qualified in the subjects they teach, and knowledgeable about English language teaching processes and practices, is multifaceted. It involves not only all partners working together, but also having adequate resources to ensure that the trainees undergo a rigorous training process and have the needed mentoring and support for their professional satisfaction.

In Nepal, the pre-service teacher training or teacher education is, according to the Pre-service Teacher (PST) Report (2017), "the training of teachers prior to their teaching career", and theoretical as well as practical in nature. Such programs are conducted by Faculty of Education (FoE) of TU. Regarding teachers' belief and satisfaction Pajares (1992, as cited in Xu, 2012, p.1397) noted that teachers' beliefs have a greater influence on the way they plan their lessons, on the kinds of decisions they make, their attitude toward job and job satisfaction, and on their general classroom practice than the teachers' knowledge. This study has adapted Pajares theory to study teachers' beliefs and satisfaction.

\section{The Study}

The purpose of this study was to explore the novice teachers' perception and practice on the pre-service teacher education courses of English in TU. Consequently, the following research questions were addressed:

1. How do the novice teachers perceive the pre-service teacher education courses of English in TU?

2. What are their beliefs on teaching profession?

3. How do they practice implementing the acquired knowledge and skills of pre-service teacher education courses in their teaching field?

I adapted narrative inquiry as the research method of qualitative research approach in order to capture the complexities of perspectives and experiences of novice teachers. According to Webster \&Mertov (2007, p.i),"Narrative inquiry provides researchers with a rich framework through which they can investigate the ways humans experience the world depicted through their stories". Similarly, in Khanal's (2009, p.241) words, "Narrative inquiry is the process of gathering information for the purpose of research through story telling ". This research was conducted in Sindhuli district of Nepal. I had selected three community schools of this district. The informants of the study includes a total of 3 novice English teachers ( 2 female, 1 male) who were teaching in different community school of Sindhuli district. They were selected following a purposive and convenience sampling technique. The informants had no more than four years of teaching experience and all voluntarily participated in this research. To ensure anonymity, alpha-numeric 
identity (T1- T3) had been used for all participants involved in this study (Ambler, 2016).

Interview technique was used to collect data. The interview, being the most common and powerful research method, enables participants to speak for themselves. The semi-structured interview was used in order to elicit in-depth data from the novice teachers on their perception, practice and beliefs about preservice teacher education courses of English in TU. Content analysis (Strauss \& Corbin, 1990; Miles \&Huberman, 1994) was used in the analysis of the data based on interviews. All interviews were first audio-recorded by the researcher after taking the informants' permission. Secondly, data was transcribed for analyzing process. Thirdly, content analysis was utilized based on the assigned codes on the text. Finally, the main themes were defined in terms of the codes given.

\section{Results and discussion}

This section discusses the results of the study in terms of perception, belief and satisfaction of novice teachers in three main subthemes.

\section{Theory-oriented courses for Teaching}

For most novice teachers, teaching in a community school after completion of preservice courses of English is exciting because there is a new environment and all circumstances are different for the teachers. When the teachers enter the class to teach, they reflect what they had studied in the pre- service teacher education courses; whether the courses is supportive or not. In this regard T1 said:

The pre- service teacher education courses of English in TU that we studied is theory-oriented where we studied methods, techniques and approaches which we use in our classroom while we are teaching. Similarly, the course is fruitful for us in the sense that it gives us ideas on teaching grammar, pronunciation, vocabulary and language functions that are the major aspects of language teaching. It helps us provide content based teaching. The courses are theory-oriented which supports lecture method but it needs to be training based focusing on participatory and task-based approach.

As it is obvious, the courses of English in TU are only partly supportive to the novice as they mainly offer content knowledge. In this regard, Yook and Lee (2016, as cited in Rouf\& Mohamed, 2017, p.3) surveyed Korean EFL teachers' perceptions of how teacher education programs affected their classroom teaching. The findings show similar outcome that pre-service teacher education programs had little impact on teachers' classroom practices as these programs were predominantly theoryoriented. According to Botha \& Reddy (2011, p.257), "pedagogical content knowledge is described as a transformation of teacher knowledge from a variety of domains of knowledge, which includes subject matter knowledge, pedagogical knowledge, and knowledge about content". However, T1 is not completely satisfied with the course as it is not practice-oriented. In order to do so, Genc (2016, p.678) suggests that, "English language teacher education programs offer practicum courses which involve teaching experiences for pre-service teachers in co-operating schools [...] an effective cooperation and collaboration need to be established between schools and pre-service teacher education programs". T2 expressed similar ideas as:

The pre-service course of English is helpful in teaching English because I practiced to teach in practice teaching 
program and I learned qualities of good teachers as well. However, what I felt from the situation where I am teaching it requires practical child centered knowledge and skills to teach the students. If our courses address such type of matter, it will be much more fruitful for novice teacher like us.

This is in line with Fajardo\& Miranda (2015) who stated that the teaching practicum allows pre-service teachers to become exposed to the real world of teaching English to students of other languages and to gain knowledge about the complexity of current classroom practices, which contribute to enhancing pre-service teachers' motivations, attitudes, and engagement towards the teaching profession. The participating teachers felt the lack of practicality in the courses which echoes Macias and Sanchez (2015) finding that pre-service teachers have difficulties during their teaching experiences as well as the decisions they made in order to maintain the control and organization of the classrooms. As practice makes the novice teacher perfect, they try to utilize the knowledge and skills they have acquired during their study. Expressing their dissatisfaction, T3 put his ideas differently:

I am neither completely satisfied with this course nor dissatisfied on the contents of the courses. Generally, the courses are okay. What is missing I think, is the modern technological aspects of the courses. I didn't learn to teach using modern technology even at M. Ed. As a novice teacher, I am feeling very difficult to teach utilizing modern technology.

Likewise, Zhiting and Hanbing (2006, as cited in Mwangi\&Khatete 2017, p.636) stated also reported similar findings:

Teacher education program in China and other parts of the world mainly train teachers in two clusters of technology courses. The first cluster falls into what he calls ICT basics, including modules such as computer basics, programming, software tools, and network applications; the second cluster is related to educational technology, including modules such as instructional media, computer-based instruction, and multimedia authoring.

Thus, teacher education courses of English in TU are not up-to-date as they do not support the recent ways of teaching English not sufficient. The practicing teachers have bitter experiences and reflection on the use of modern technology in the classroom in the sense that they do not know how to use modern technology because the courses did not have that provision.

\section{Strong beliefs on teaching profession}

Belief is the most important aspect in teaching profession. The teachers, who have strong beliefs in teaching profession, can teach effectively. In other words, teachers' beliefs are important quality for teaching. Talking about teachers' beliefs, T2 said," I entered into teaching profession because I like this profession very much from my childhood days and I have strong belief that I can do the best in this profession. I want to be identified as a good teacher, so I am trying my best for that". Murphy, Delli, and Edwards (2004) asserted that teacher beliefs are formed based on experience both in the classroom as a teacher and as a student. Early formed beliefs are strong and resistant to change, which means what someone believes is good teaching could be based in childhood experiences. Beliefs play an important role in many aspects of teaching as well as in life. Guotao (1997, as cited in $\mathrm{Xu}, 2012$ ) also stated that a teacher's beliefs are formed during the teaching 
process and reflect the teacher's subjective knowledge of relevant educational phenomenon, especially towards his/her own teaching ability.

\section{$\mathrm{T} 1$ and $\mathrm{T} 3$ agreed in that;}

Family background and members of family encouraged us to involve in teaching profession because they have strong belief on this profession. As teachers, we think that we should respect students' autonomy and creativity in learning and provide ample opportunity for them to be creative and independent learners.

This observation demonstrates that teacher' beliefs on teaching profession is not only confined to the professional development of teachers but also related to the development of students as well. In the similar type of the study (Xu, 2012, p.1401) mentioned that, "the formation of a teacher's educational beliefs in the language teaching-learning process will exert an imperceptible influence on forming active language teaching methods and will bring about an improvement in students' language abilities". Teacher's beliefs are more influential than a teacher's knowledge on determining his or her teaching activities. Thus, it is important that teacher educators uncover particular beliefs that facilitate the efficacy of teacher education.

\section{Satisfaction in teaching}

Satisfaction is generally considered the difference between what is expected or desired compared to what is actually experienced. Job satisfaction occurs when someone feels he/she has proficiency, value, and is worthy of recognition (Garcez, 2006). Job satisfaction is a positive or pleasant emotional state resulting from a person's appreciation of his/ her own job.
Being novice teacher, the participants of this study are satisfied in their profession.

Expressing satisfaction in teaching, T1 stated," I am satisfied with teaching profession because I have got opportunity to apply what I have learnt in pre-service teacher education courses. Likewise, I have earned money to run my family and I have social image as a teacher in my society". This illustrates that novice teachers are satisfied and are working effectively in schools in the sense that they are satisfied with their profession. T2 and T3 disagreed this way:

We are unsatisfied in some aspects of the pre-service teacher education courses. Some courses are not applicable and useful for us because when we are teaching, we never find their use in the classroom. The contents of the courses such as 'Expanding Horizon in English',' English for Mass Communication', 'Pedagogical grammar' are not frequently used in course of teaching English language in classroom.

The participants expressed the opinion that some courses of pre-service teacher education course were not relevant to the novice teachers to teach English in the classroom. Consequently, it was because of these irrelevant courses, they were unsatisfied in the teaching profession.

To sum up this section, the participating teachers were dissatisfied and had somewhat negative attitude towards TU's TE programs and practices because most of the courses were (a) theory-oriented, (b) not practice oriented, (c) not uptodate, and (d) out of touch of the classroom realities. They were unsatisfied because they did not have a strong faith that the programs trained the teachers well. They were unhappy because most of the training they received was 'useless' when it came to classroom practices. 


\section{Findings and implications}

Teacher education program and its courses of English in TU are helpful to the novice teachers as this program provides the content-based knowledge which is appropriate to them to teach to the students. However, the courses are mostly theory oriented and lack practical aspects that are of great significance to novice teachers. The courses are inadequate for the novice teachers and do not help them gain proper theoretical as well as practical knowledge to use modern technology in the classroom. To address this gap in the courses, they must be improved focusing on their practicality and current demand of the profession.

The novice teachers have strong belief in teaching career. Their beliefs in teaching profession is not only confined to their professional development but also related to the development of students as well. They are dedicated in their work because they are surviving through this occupation. The beliefs of novice teachers in teaching profession need to be continued and facilitated.

Novice teachers are contented in their profession as they are working effectively in their teaching field. Some courses of preservice teacher education program are not practically relevant to them because these courses never assist them in teaching. The courses that are irrelevant need to be revised to make their use purposeful for novice teachers in teaching English.

\section{Limitations of the study and suggestion for further research}

This study had some limitations in terms of sample size, research site and the research area. It had included very small sample size because of which the finding of this study cannot be generalized. The site of the study was only Sindhuli district. The research area was only pre-service teacher education courses of English of M. Ed. in TU. The findings of the study, therefore, have limited applicability.

\section{Conclusion}

This study, applied qualitative research following narrative inquiry with three participants, explored the perception, practice and belief of novice teachers on pre-service teacher education courses of English in TU. The participants reported that there was more emphasis on theory rather than practice in the teacher education program of English in TU. They believe that the knowledge and skills that they have acquired in teacher education program practically in their field are only partially useful. They suggest that the courses need to be practical-based focusing on modern information technology instead of imposing the bundle of theoretical knowledge.

\section{References}

Akcan, S. (2016). Novice non-native English teachers' reflections on their teacher education programmes and their first years of teaching. PROFILE Issues in Teachers' Professional Development, 18(1), 55-70. Retrieved from https://doi.org/10.15446/ profile.v18n1.48608.

Ambler, T. B. (2016). The day-to-day work of primary school teachers: A source of professional learning. Professional Development in Education, 42(2), 276289.Retrieved from: http:// dx.doi.org/10.1080/ 19415257.2014. 998343.

Bentea, C. C., \& Anghelache, V. (2012).Teachers' motivation and satisfaction for professional activity. Social and Behavioral Sciences, 33, 563 - 567.doi:10.1016/j.sbspro.2012.01.184 
Beltman, S., Glass,C., Dinham, J., Chalk, B. and Nguyen,B.(2015).Drawing identity: Beginning pre-service teachers' professional identities. Issues in Educational Research, 25(3), 225245.Retrieved from: http:// www.iier.org.au/iier25/beltman.pdf.

Botha, M. L. \& Reddy, C. P. S. (2011). Inservice teachers' perspectives of preservice teachers'

knowledge domains in science. South African Journal of Education, 31, 257274.Retrieved from: http:// sajournalofeducation.co.za / index.php/saje/article / viewFile/ $354 / 238$.

Cakmak, M. (2013). Learning from teaching experiences: Novice teachers' thoughts. H. U. Journal of Education, 1,55-67. Retrieved from:http:// www.efdergi.hacettepe. edu.tr/ upload/files/icindekiler-ozel-saii.pdf.

Danish, R \& Usman, A. (2010). Impact of reward and recognition on job satisfaction and motivation: An empirical study from Pakistan. International Journal of Business and Management, (5) 2, 195-167.

Faculty of Education, TU. (6th April, 2018). Retrieved from http://tribhuvan university. edu.np/faculties/facultyof-education/.

Faez, F., \& Valeo, A. (2012). TESOL teacher education: Novice teachers' perceptions of their preparedness and efficacy in the classroom. TESOL Quarterly, 46(3), 450-471. Retrieved from: http://dx.doi.org/10.1002/ tesq.37.

Fajardo, J. A., \& Miranda, I. R. (2015). The paradox of the practicum: Affinity to and resistance towards teaching. Ikala, Revista de Lenguaje y Cultura, 20(3), 329-341. Retrieved from: https:// aprendeenlinea.udea.edu.co/ revistas/index.php/ikala/article/ view/18495.

Freeman, D. (2001). Second language teacher education. In D. Nunan\& R. Carter (Eds.), The Cambridge guide to teaching English to speakers of other languages (pp. 72-79). Cambridge, UK: Cam-bridge University Press. Retrieved from: https://doi.org/ 10.1017/ CBO9780511667206.011.

Garcez , C. (2006). Job satisfaction: The challenges transformed organizations face. Retrieved from http:// a p l a w re n c e.com / M i s c / job_satisfaction.html.

Genc, Z. S. (2016 ).More practice for preservice teachers and more theory for inserviceteachers of English language. Social and Behavioral Sciences, 232, 677683.doi: 10.1016/ j.sbspro.2016.10.092.

Goals for Teacher Education (2016 2019).Teacher Student Union of Finland - SOOL. Retrieved from:https:/ / www.sool.fi/site/ assets/files/1338/goals_for_teacher_ education_2016-2019.pdf.

Goff-Kfouri, C. A.( 2013). Pre-service Teachers and Teacher Education. Social and Behavioral Sciences 93 (2013 ) 1786 - 1790. doi: 10.1016/ j.sbspro.2013.10.117

Hismanoglu, M., \& Hismanoglu, S. (2010).English Language Teachers' Perceptions Of Educational Supervision In Relation To Their Professional Development: A Case Study Of Northern Cyprus. NovitasROYAL (Research on Youth and Language), 4 (1),16-34. Retrieved from: https://www.pegem.net/dosyalar/ dokuman/124491-20110815154517hismanoglu.pdf. 
Johnson, K. E. (1996). The vision versus the reality: The ten-sions of the TESOL Practicum. In D. Freeman \& J. C. Richards (Eds.), Teacher learning in language teaching, 30-49. New York, NY: Cambridge University Press.

Kaur, A. (2013). Maslow's Need Hierarchy Theory: Applications and Criticisms. Global Journal of Management and Business Studies. 3(10).1061-1064. Retrieved from: http:// www.ripublication.com/gjmbs.htm.

Khanal, P (2009). Educational research. Kathmandu: Sunlight Publication.

Kim, K. \& Roth, G. (2011). Novice teachers and their acquisition of work-related

information. Current Issues in Education, 14(1). Retrieved from http:// cie.asu.edu/

Loughran, J. (2006).Developing pedagogy of teacher education; Understanding teaching and learning about teaching. NewYork: Routledge.

Macias, D. F., \& Sanchez, J. A. (2015). Classroom management: A persistent challenge for pre-ser-vice foreign language teachers. Profile: Issues in Teachers' Professional Development, 17(2), 81-99. https://doi.org/ $10.15446 /$ profile.v17n2.43641.

Maslow, A. H. (1943). A theory of human motivation. Psychological Review, 50(4), 370-96.

Melita, D. \& Katitia, O. (2015).Teacher education preparation program for the 21 st century which way forward for Kenya? Journal of Education and Practice, 6 (24), 57-64. Retrieved from:www.iiste.org.

Mergler, A. \& Spooner-Lane, R. (2012). What pre-service teachers need to know to be effective at values-based education.
Australian Journal of Teacher Education, 37 (8), 66-81. Retrieved from: https:/ / files.eric.ed.gov / fulltext / EJ995221.pdf.

Murphy, P. K., Delli, L. A. M., \& Edwards, M. N. (2004). The good teacher and good teaching: Comparing beliefs of second grade students. Pre-service teachers, and in- service teachers. The Journal of Experimental Education, 72(2), 69-92.

Okas, A. Schaaf, M. and Krull, E. (2014). Novice and experienced teachers' views on professionalism.Trames, 18(68/63), 4, 327-344. Retrieved from: http: / / www.kirj.ee/public / trames_pdf/2014/issue_4/trames2014-4-327-344.pdfPre-service Teacher Education in Nepal: A Qualitative Case Study (PRT Report). Retrieved from: http:/ / ncenepal.org.np/wp-content/ uploads/2017/11/PST-report-finalcopy.pdf.

Rhodes, R. (2017). Supporting novice teachers: Peer coaching and collaborative inquiry as support. Doctor of Education in Teacher Leadership Dissertations, 15.

Retrieved from http://digitalcommons. kennesaw.edu/teachleaddoc_etd/15.

Robinson-Pant, A. (2000), Why eat green cucumbers at the time of dying? Women's literacy and development in Nepal. UNESCO Institute for Education. Retrieved from www.unesco.org/ education/uie.

Rouf, A. \& Mohamed, A.R. (2017). Secondary EL teachers' CPD: Present practices and perceived needs. Journal of NELTA 22(1-2),1-12.

Tarone, E., \& Allwright, D. (2005). Second language teacher learning and student second language learning: Shaping the knowledge base. In D. J. Tedick (Ed.), 
Second lan-guage teacher education: International perspectives, 5-23. Mahwah, NJ: Lawrence Erlbaum.

Webster L. \& Mertov, P. (2007). Using narrative inquiry as a research method an introduction to using critical event narrative analysis in research on learning and teaching. Milton Park, Abingdon: Routledge.

$\mathrm{Xu}, \mathrm{L}$. (2012). The role of teachers' beliefs in the language teaching-learning process. Theory and Practice in Language Studies, 2(7), 1397-1402. doi:10.4304/tpls.2.7.1397-1402.

\section{Appendix 1}

\section{Guideline Questions for Interview}

1. Could please briefly introduce yourself and tell me your experiences as a student of Faculty of Education.

2. Explain me your experiences as the novice teacher in teaching profession. How do you feel? What were the problems?

3. What is your perception regarding the pre-service teacher education courses of English in TU that you have completed?

4. Do you think the courses are relevant to you for teaching in the classroom? Are they supportive? Do you utilize the reflection of the courses in terms of teaching?

5. How do you perceive these courses to prepare you as a good teacher: theoretically or practically applicable?

6. Have you faced any practical difficulties in implementing the knowledge that you have gained in teacher education program?

7. How are you implementing the acquired knowledge and skills of preservice teacher education courses in the classroom?

8. Why do you select teaching profession? What is your belief on this profession? How do you perceive teaching profession?

9. Do you think you are satisfied with these courses? And Why?

10. Are there any courses that are not completely irrelevant in terms of conducting teaching and learning activities in the classroom?

11. Are you satisfied with your profession? How do you feel in teaching in community school of Nepal? Do the courses of teacher education of TU help you to be a good teacher?

\section{Contributor}

Nani Babu Ghimire is a Lecturer at Siddha Jyoti Education Campus Sindhuli, Nepal. He has completed Master's Degree in English Education and English in Arts from Tribhuvan University. He is currently an M. Phil scholar in English Education at Tribhuvan University. He is interested in teacher professional development, multilingualism, diversity in language education and critical pedagogy. 